\title{
Wali Nanggroe Institution: The Role, Function, and Strategy for Resolving Conflicts in Aceh after the Peace
}

\author{
Zulham Ibrahim \\ Department of Political Science, Faculty of Social and Political Sciences, \\ Malikussaleh University, 24531, Lhokseumawe, Aceh Province, Indonesia \\ Corresponding Author: zulhambere@gmail.com
}

\section{ARTICLE INFO}

\section{Publication Info:}

Research Article

\section{How to cite:}

Ibrahim, Z. (2020). Wali

Nanggroe Institution: The Role, Function, and Strategy for Resolving Conflict in Aceh after the Peace. Society, 8(2), 313-324.

DOI : 10.33019/society.v8i2.192

Copyright (c) 2020. Owned by Author(s), published by Society

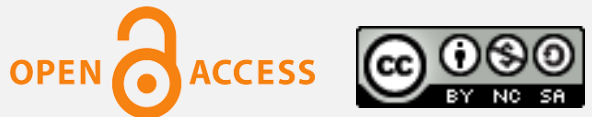

This is an open-access article.

License: Attribution-

NonCommercial-ShareAlike

(CC BY-NC-SA)

Received: June 10, 2020;

Accepted: July 4, 2020;

Published: July 31, 2020;

\section{ABSTRACT}

Wali Nanggroe Institution is an institution of cultural authority as the unifier of the people that is independent, authoritative, and has the authority to develop and oversee the implementation of the life, adat (custom), language, the award of titles and honors, and adat rites. This research was conducted in Banda Aceh city using a qualitative method. The concept used was Wali Nanggroe, the theories of strategy, conflict resolution, and political communication theories to resolve local conflicts and analyze Wali Nanggroe neutrality in resolving conflicts in Aceh. The data were obtained by observation technique and interview (questionnaires and voice records). The results found that the Wali Nanggroe Institution does not implement a strategy in resolving conflicts both local conflicts and other conflicts in local institutions. Also, Wali Nanggroe does not hold political communication to resolve the conflicts. Besides, as a mediator, Wali Nanggroe is unfair to resolve the conflicts among local institutions due to some causes; emotional attachment between Wali Nanggroe and Members of Parliament at Aceh Provincial House of Representatives (DPRA) from Aceh Party Faction, tend to maintain the reign of Wali Nanggroe, and procedural problems in Wali Nanggroe election.
Keywords: Aceh, Conflict; Local Institution; Resolution; Wali Nanggroe

Copyright $($ 2020. Owned by Author(s), published by Society. This is an open-access article under the CC-BY-NC-SA license. 


\section{Introduction}

The Law on the Governing of Aceh (Indonesia: UUPA) regulates several things: Firstly, the Wali Nanggroe Institution constitute adat (a traditional customary) leadership as a unifier of the people that is independent, has the authority and has the jurisdiction to develop and oversee the implementation of adat institutions and adat affairs, the awarding of titles and honors, and the exercising of other adat rites. This institution shall be led by Wali Nanggroe, as regulated by Aceh's Qanun/UUPA Number 8/2012 (Article 96). Secondly, Wali Nanggroe has the right to award titles and adat titles to individuals or organizations, whether domestic and overseas, according to criteria and procedures governed by Aceh's Qanun/UUPA Number 8/2012 (Article 97) (Abdullah, 2016, pp. 284-286).

Regarding adat institutions, it is stated: First, adat institutions shall function and serve as a means for public participation in the Governing of Aceh and the governing of districts/municipalities in the areas of security, peace, harmony, and public order. Resolution of community social problems through traditional means shall be carried out by adat institutions including Aceh Adat Council; Imeum Mukim or by any other name it is referred to; Imeum Chik or by any other name it is referred to; Keuchik or by any other name it is referred to; Tuha Peut or by any other name it is referred to; Tuha Lapan or by any other name it is referred to; Imeum Meunasah or by any other name it is referred to; Keujreun Blang or by any other name it is referred to; Panglima Laot or by any other name it is referred to; Pawang Glee or by any other name it is referred to; Peutua Seuneubok or by any other name it is referred to; Haria Peukan or by any other name it is referred to; and Syahbanda or by any other name it is referred to (Article 98). Secondly, the fostering of adat life and adat affairs shall be conducted following the development of the specialness and uniqueness of Aceh that is founded upon the principles of Islamic Law (Sharia) and implemented by the Wali Nanggroe. Formulation of adat provisions that apply generally to the people of Aceh shall be implemented by adat institutions with advisement from the Wali Nanggroe (Article 99) (Abdullah, 2016, pp. 284-286).

The above clauses show that the Law on the Governing of Aceh gives large legality to the Wali Nanggroe Institution due to its roles. One of its functions is the unifier of all people in Aceh beside the security, peace, harmony, and public order. The resolution of customary social problems is pursued through the adat institution. In its development, Aceh still experiences conflicts both locally and institutionally. The conflicts reveal that Wali Nanggroe incapable to resolve the conflicts that crucial among people in Aceh such as the conflicts between institutions and other conflicts. The conflicts, some other conflicts that have already been resolved such as the resolution of conflicts taken by the local government of Southwest Aceh to resolve the dispute of land by having a legal recourse since the path to persuasion (non-litigation) has not been met negotiations as conducted by the Fact-Finding Team and the Special Committee of the West Aceh House of Representatives (DPRK Aceh Barat) with the fishing community and documents prove the land was owned by the Government of North Aceh Regency. The fishing community does not have any evidence to prove due to the loss of their documents in the tsunami disaster 2004 (Nurlian, 2018, p. 185). The Province of Aceh has many special features compared to other provinces, such as special autonomy. From a political perspective, Aceh is also characterized by political and social features, such as the presence of local political parties and the Wali Nanggroe Institution. However, Aceh is a province that has just recovered from the conflict between the separatist movement and the central government, so the communication conflicts occur between the executive and legislative branches have a different character compared to the communication and social conflicts that exist in other provinces.

Copyright ( ) 2020. Owned by Author(s), published by Society. This is an open-access article under the CC-BY-NC-SA license. 
After Aceh's peace, the executive power of the Aceh government is still held by former high officials of the Free Aceh Movement (GAM) from the Aceh Party (PA). Apart from it was, GAM is not as solid as once was. To give an instance, Muzakkir Manaf (GAM's Supreme Commander) and Irwandi Yusuf (GAM Leader) are both frontmen of GAM. A few years after Aceh's peace, the two men broke ideologically and left GAM. Yet, both of them built their respective local political parties. Muallim (a nickname which is often attached to Muzakir Manaf), already has the Aceh Party (PA) and Irwandi Yusuf founded the Nanggroe Aceh Party (PNA). Their different ideologies are rooted in the holistic problem of GAM's internal divisions. It also impacts on the leadership of regional heads, they intercept each other if one of their parties leads Aceh, both as Governor and Member of Parliament often occurs.

The birth of the Wali Nanggroe Institution was a mandate of the peace agreement between GAM and the Government of Indonesia. Initially, Wali Nanggroe was expected to protect and resolve social conflicts and institutional conflicts that occur in Aceh with dignity, integrity, and civilization. The people of Aceh thought that Wali Nanggroe was capable of uniting the communities in Aceh for any conflicts, especially if these conflicts can lead to the disunity of the people. Yet, in reality, the institution does not resolve social and institutional conflicts as it should.

Even though Aceh and the Central Government have been in peaceful understanding, however, the conflict among institutions still occurs, such as between the Governor and the Aceh legislature. These acts of violence often emerge on the alibi that the institutions in charge of handling them do not pay any serious attention, even sometimes, do not care at all. So, either an institution or society ways, they need to take over this task by acting on it themselves directly, without going through legal channels (Rasyidah, 2014, p. 53). The emergence of the center node in an institution is an unavoidable phenomenon, so it needs Wali Nanggroe Institution as a mediator that each conflict has different intensity as well. Likewise, the conflict occurs after Aceh peace, among institutions in the capital of Aceh Province was part of the highintensity conflict. The conflict after Aceh peace such as the conflict of communication, politics, and other social issues between institutions and the community. Based on the description above, it is interested in studying the strategy of Wali Nanggroe to resolve local conflicts, and analyzing its neutrality in resolving conflicts in the local institutions after Aceh peace.

\section{Literature Review}

According to Aceh's Qanun Number 8/2012 concerning the Wali Nanggroe Institution, in Article 1, paragraphs 3 and 4, Wali Nanggroe Institution is an institution of cultural authority as the unifier of the people that is independent, authoritative, and has the authority to develop and oversee the implementation of the life, adat (custom), language, the award of titles and honors, and adat rites. While in paragraph 3 of the article also explains the Wali Nanggroe is a personal and independent leader who leads the Wali Nanggroe Institution (Pemerintah Aceh, 2012). Besides, the role of Wali Nanggroe was also strengthened by Law of the Republic of Indonesia Number 11/2006 concerning the Government of Aceh as a follow-up to the Memorandum of Understanding (MoU) between the Republic of Indonesia and the Free Aceh Movement (GAM) in Helsinki on August 15, 2005. Item 1.7.1 The Helsinki MoU emphasized that the Wali Nanggroe Institution would be formed with all its ceremonial instruments and titles. This means that this institution is more directed towards adat institutions rather than government and political institutions (Husin, 2013, p. 26). This concept is used due to it is considered relevant to investigate the functions and duties of the Wali Nanggroe in solving

Copyright (C 2020. Owned by Author(s), published by Society. This is an open-access article under the CC-BY-NC-SA license.

https://doi.org/10.33019/society.v8i2.192

315 
problems that occur among people of Aceh such as guidance, independence of institutions, and authority in the resolution of cases occur.

The conflicts occur after Aceh's peace, the theory of conflict has emphasized that society will not always be in order. Any society must have experienced conflicts or tensions. Then conflict theory also described domination, coercion, and power in society. Conflict theory also describes these different authorities resulting in superordinate and subordinate. The difference between superordinate and subordinate can lead to conflict due to the differences in interests (Tualeka, 2017, p. 34). Furthermore, in research from Khomsahrial (2014, pp. 111-112) said that the conflict refers to individuals or groups that can increase tension as a result of a mutual obstruction in achieving goals as stated as follows: Conflict is a dispute, a conflict between two persons or two groups where one action is against the other so that one or both are interdependent. The last two opinions consider that conflict between individuals and groups as a behavior that interferes with the achievement of organizational goals. Thus conflict is interpreted as an event that can destroy the organization.

In the context of Aceh, it is necessary to think of a conflict resolution as in research from Amantjik et al, (2019, p. 59) stated that to conduct a conflict resolution analysis, it needs certain approaches as follows: 1) the dynamics of the conflict; 2) need-based; and 3) strategic calculation. In the dynamics of the conflict approach, conflict is viewed as a dynamic phenomenon, where an actor takes an action in response to actions of other actors, which continues to increase to subsequent actions that make it difficult to determine which side is more. In research from Heridiansyah (2014, p. 28) argued that conflict management is a series of actions and reactions between actors both inside and outside of the conflict. Conflict management includes a process-oriented approach that directs to forms of communication from actors and beyond the actors and how they affect interests and interpretations. In an organization, the work of individuals and groups of workers are interrelated with the work of other parties. When a conflict arises within an organization or institution, the cause is always identified as poor communication.

Aceh is a province that implements Islamic law, in resolving conflicts, it is in the right track to view conflict resolution from an Islamic perspective, as a new way that contributes to 'conflict' by taking into account the currently developing science. The concept of Hakam in the Holy Quran is not others are precise as progress in the development of Islamic thoughts, where each conflict takes place a Hakam or peacemaker that can create an atmosphere of conflict becomes peaceful. With the spirit of Hakam, it strengthens the mediation system that develops in conflict resolution since only a mediation system a peacemaker can take a neutral attitude and only have a goal, such to reconcile the parties to the conflict (Rifa'i, 2010, p. 185). A Hakam (mediator) is meant to take steps to achieve peace in conflict. Whatever the source of the problem, the following five steps are fundamental in overcoming difficulties: a) Introduction, b) Diagnosis, c) Agree on a solution, d) Implementation, e) Evaluation (Stevenin as cited in Muspawi, 2014, p. 46).

Regarding the case background of Aceh, to end the conflict, in research from Liliweri (2018) suggested as follows: (1) avoiding; (2) conquering; (3) ending the conflict procedurally, including reconciliation, compromising ... (p. 614). Also, the resolution of social and institutional conflicts in Aceh needs to be built by public trust. The failure of community reconciliation after communal conflict caused by the reconciliation process has not touched the roots of the conflict so that it is then compounded by distrust between communities that lead to social segregation. This reconciliation failure can only be implemented by rebuilding a longterm peace process based on trust. As an effort to reconcile peace (reconciliation) of post-conflict

Copyright ( ) 2020. Owned by Author(s), published by Society. This is an open-access article under the CC-BY-NC-SA license. https://doi.org/10.33019/society.v8i2.192 
trust-community based, four indicators must be implemented; fostering the people's wishes, fostering cooperation among community groups, fostering honesty, and instilling an attitude of loyalty as a form of community service to the interests. The community reconciliation mechanism carried out by the government and non-government institutions should be carried out continuously and participatory by involving local communities as conflict reconciler (Anwar, 2015, p. 141).

The description above is a strategic choice for resolving conflict after Aceh peace. A strategy is a crucial step that requires careful handling in communication planning and social conflict, if the choice of strategy is inaccurate or mistakes then the results obtained can be fatal, such as losses of time, material and energy (Cangara, 2014, p. 65). In research from Effendy (2007, p. 301) also added that the conflict issues in Aceh need to be supported by a communication strategy which is a combination of communication planning and communication management to achieve a goal. To achieve these objectives, the communication strategy must be able to demonstrate how operations must be implemented tactically, the approach can differ, depends on certain situations and conditions.

\section{Research Methodology}

This research used qualitative research methods. The qualitative approach seeks to interpret the meaning of events as interactions of human behavior in certain situations. This research was descriptive, such as a problem-solving process that is investigated by describing the state of the subject and object of research at present based on facts (Moleong, 2010, p. 3). The informants are persons who provide information/data as the primary data/information to be obtained (Moleong, 2010, p. 6). The informants were those considered capable of providing information. Informants are determined purposively based on the criteria owned by the informants themselves. The informants were the Chairperson of Wali Nanggroe (Tuha Peut), the Chairman of Aceh House of Representatives (DPRA) Commission I from the Aceh Party (PA) Faction, the Vice-Chairman of DPRA Commission IV and Chairperson of National Mandate Party (PAN) Faction, Administrative Section Head of Aceh Legislation Regulations, Assistant for the Government at the Aceh Regional Secretariat, Senior Legal Expert of Syiah Kuala University, Chairman of the DPRA from the Aceh Party (PA) Faction, Member of Parliament at DPRA from the United Development Party (PPP) Faction, Member of Parliament at North Aceh Regency House of Representatives (DPRK Aceh Utara) from Democratic Party Faction, and Academicians of Malikussaleh University.

The stages of data collection and analysis were as follows:

1) Literature study. The data were obtained from journals, books, regulations, and other relevant documents to support this research.

2) In-depth interviews. The interview process was structured and unstructured. Unstructured interviews do not use any set questions, instead, the interviewer asks open-ended questions based on a specific research topic, and will try to let the interview flow like a natural conversation. The interviewer modifies his or her questions to suit the candidate's specific experiences and information.

3) Documentation. The documentation process is a method of collecting data using documents related to the object of the research. The secondary data obtained through literature, such as legislation, books related to obtain a theoretical foundation (Sugiyono, 2009, p. 156). 
After all the data had been collected, the next step was analysis. The data are then analyzed in a qualitative descriptive method, as well as quotations from the results of interviews processed to support the analysis. The use of data analysis was to solve problems that arose in this research; from the beginning until the completion of data collection. Data verification was carried out continuously throughout the research process. Since first entering the field and during the data collection process, have attempted to analyze and search for the meaning of the data collected (Moleong, 2010, p. 5).

\section{Results and Discussion}

Since the Helsinki agreement on August 15, 2005, the people welcomed this peace agreement (between GAM and the Government of the Republic of Indonesia or Central Government) as they hope that after Aceh peace this land would be built and Indonesia in general. Also, it is hoped that after the conflict, the sustainable development accompanied by peace can create a new social order in Aceh. The presence of Wali Nanggroe is a bridge towards peace. People of Aceh trust Wali Nanggroe for their discretion and as an arbiter in any social conflict that will occur in the future. The peace has authorized Wali Nanggroe to use its power as a mediator and conflict resolver that occurred in Aceh.

\subsection{The Strategy of Wali Nanggroe for Resolving Local Conflicts}

The conflict in Aceh is different from other regions such as the conflict in Papua that occurred between the Government of Indonesia and the OPM (Free Papua Movement) as a conflict with the roots of complex problems, ranging from historical problems, ideology, to the injustice sense of the Papuan. The opposition occurred is not only for the independent but also for social and economic justice. Conflict resolution that has been implemented by both parties is still considered ineffective. The most effective conflict resolution is by holding a dialogue between the two parties. Through the horse-trading mechanism, the implementation of dialogue can run more effectively and both parties can express their wishes openly. Various adaptations are also needed in conducting dialogue between them. Changing the level of actors as well as the agenda in the dialogue are substances that are considered important to be harmonized by the Government of Indonesia to achieve peace. Commitment to conducting dialogue must be fulfilled by both parties to create the desired conflict resolution (Febrianti et al., 2019, p. 106).

In each key period of Aceh's history, Ulama (a body of Muslim scholars recognized as having specialist knowledge of Islamic sacred law and theology) always appears as a force that gives a religious ethical foundation for every socio-political change and subsequently acts as a successor to the religious style that develops in the society. During the conflict, the role of Ulama was not so significant due to the political constellation that occurred. Polarized scholars and their influence are weakening. Yet institutionally, the role of Ulama has not changed and is always present in the life of the people until they take part in initiating peace. After the conflict, the Ulama position was re-strengthened and in the process of reconciliation, their roles were related to four things: 1) Transmission of knowledge, 2) As a decision-maker related to the existing law in Islam, 3) Ulama as a mediator, 4) Cultural role, as agents who are actively involved in resolving disputes that occur among society (Sahlan et al., 2019, pp. 285-286). However, in the context of the conflict between local institutions, the people expected a third party other than the Ulama. The Ulama role is less attractive for resolving the conflicts in the institution. 
Mediation can be an option as the strategy to resolve the conflict in Aceh since it is very necessary for conflict resolution and political communication. Aceh has some actors that have a lot of experience in social life. Wali Nanggroe is the figure as an elder. It is such a culture in any region that parents or older men should be prioritized in many ways, including their roles in solving problems that occur around their neighborhood. The role of Wali Nanggroe is very clear according to the law of the Government of Aceh. That becomes a problem solver of all problems that occur in local government. Wali Nanggroe until today does not implement any strategies to resolve local conflicts and others that occurred in Aceh. Wali Nanggroe is extremely passive in responding to the social phenomena that occurred so that the role of a facilitator who mediated conflicts could not be carried out optimally. This situation was not in line with the theory of conflict resolution as a mediator in resolving the conflict itself. Apart from that, other senior figures who have led Aceh both in the executive and legislative institutions, which are undoubted of their political expertise and progress and of course their communication abilities need to be considered in resolving the existing conflicts. Yet normatively Wali Nanggroe has a more legal role in resolving conflicts to unite the people of Aceh so that it becomes a stumbling block to the emergence of the other figures outside Wali Nanggroe Institution that more capable to resolve conflicts in Aceh.

This argument reinforces the important role of a mediator. If the Governor has the integrity solving any kinds of problems in Aceh, like the policies, decisions, and Aceh Government budget (APBA) is in the rules and modesty with high gratitude on the respected institution, Wali Nanggroe, Members of Parliament expect Irwandi Yusuf (Governor of Aceh Province in the period 2007-2012 and from 2017 to 2018) requests for opinions or suggestions and make Wali Nanggroe as a mediator for resolving Aceh conflict, APBA conflict, and others. The causes of conflict and political communication will be resolved properly and wisely without involving the Central Government or the Minister of Home Affairs of the Republic of Indonesia. Zero achievements and meeting points between institutions such as the executive-legislative on policy in recent years, and continue to be preoccupied with the chaos and deadlock is only disgraced.

Strategies for resolving conflicts and political communication of Wali Nanggroe Institution must involve neutral parties and their credibility. According to conflict resolution theory, the conflict must exist in social and political life. In the context of state conflict, it is common to emerge. In a modern approach, conflict is considered as a positive, if the solution is to uphold the rights of the two parties in conflict, such as institutions in Aceh. The most important thing is to involve an approved mediator. However, during the Irwandi Yusuf period, the executive did not find an independent actor who could solve the root causes of resolving conflicts and political communication.

Culturally, Wali Nanggroe is considered capable of mediating the Aceh conflict and political communication, yet, Wali Nanggroe has other interests, the powers. So those, not only the executive consider Wali Nanggroe as a role model and problem solver of Aceh, but also the public. The absence of a neutral party, conflict, and political communication between institutions will not be resolved. In the medium term, conflict and communication can still be overcome due to the changes in leadership, although similar cases will reoccur for the long term. Wali Nanggroe has a strategic role since it is part of the elite in Aceh. Still, it is regrettable that its significant role in the region is only owned by certain political elites.

From the description above, it is necessary to involve Wali Nanggroe as a mediator to resolve conflicts and communication between institutions in Aceh, such as the executive-legislative conflicts. However, the questions sometimes arise in the minds of the executive and members of

Copyright ( ) 2020. Owned by Author(s), published by Society. This is an open-access article under the CC-BY-NC-SA license. https://doi.org/10.33019/society.v8i2.192 
the legislative body whether the Wali Nanggroe capacity does exist as it is, or it only seeks a safe position. Some legislators assume that Wali Nanggroe is only looking for power. In the context of national, its position is not very strong, however, in the Aceh government; Wali Nanggroe has a strong position. The reason makes sense; the Wali Nanggroe must have a secure position. Sooner or later, Wali Nanggroe will experience political consequences if the Aceh Party is no longer the majority in the Aceh Provincial House of Representatives. Wali Nanggroe expects will be reelected whoever becomes governor.

\subsection{The Neutrality of Wali Nanggroe in Resolving conflicts among local Institutions}

The mandate of the Memorandum of Understanding (MoU) between GAM and The Government of Indonesia strongly guarantees the existence of Wali Nanggroe as an institution that can provide unity and peace for the people in Aceh. The people pin their hopes to Wali Nanggroe Institution to play a vital role in the social order. This role does not only present when resolving conflicts between regional elites but also among others. Its authority has been agreed upon by all elements since its emergence as a unifier of the people in Aceh. In reality, Wali Nanggroe is still doubtful about its neutrality. Governor of Aceh, Irwandi Yusuf, saw the figure of Wali Nanggroe as a reincarnation of the Aceh Party due to Wali Nanggroe is still active as an advisor to the Aceh Party. This alliance is what makes Aceh government officials reluctant to involve the prominent figure. If Wali Nanggroe Institution cares for peace in Aceh, without being invited he can summon the two institutions to discuss differences and similarities that exist between the executive and legislative branches and other institutions as a source of conflict. Unfortunately, the Wali Nanggroe Institution only witnessed the conflict. This means that the Wali's presence in Aceh does not function as it should. The Wali Nanggroe sits and does nothing for the benefit of the Aceh government. This silence can be understood as a political stance that supports the Aceh party and does not favor the people.

The role and position of Wali Nanggroe is only a symbol. The Central Government imposes limits on the power of Wali Nanggroe only for Aceh territory. With these territorial limitations, Wali Nanggroe was very careful in his attitude and action since a consequence of the weakness of its power from the Central Government, where this institution can and will always eliminate it if it is deemed unnecessary in the future. Today, Wali Nanggroe's strong political power is supported by legislators from the Aceh Party. The Aceh Party was used as a protector to support the Wali Nanggroe Institution so it continued to exist and the current Wali Nanggroe could remain as a permanent institution. On the other hand, Members of Parliament from the Aceh Party (PA) strongly advocated the role of Wali Nanggroe that is a party official. Some factors make Wali Nanggroe unable to be neutral in resolving conflicts in Aceh are as follows:

\subsubsection{The Emotional Attachment between Wali Nanggroe and Members of Aceh Provincial House of Representatives from Aceh Party (PA)}

The emotional attachment between the Aceh Party legislature and Wali Nanggroe becomes an indicator of the non-neutrality functions of the Wali Nanggroe to be involved in executive and legislative conflicts and other conflicts in Aceh. Wali Nanggroe takes advantage of Aceh's Member of Parliament as his guards for personal interests. Likewise, the members of the Aceh Party's legislature protected the existence of Wali Nanggroe in return for being able to point them back into legislative candidates and other powers. It is illustrated that the Chairman of the Aceh Provincial House of Representatives (DPRA) never communicated with Wali Nanggroe about the on-going conflict and chaotic political communication. The Chairman of the

Copyright ( ) 2020. Owned by Author(s), published by Society. This is an open-access article under the CC-BY-NC-SA license. 
DPRA concern about his position if he acts out of the line and the direction of the Aceh Party functionary elite such as Wali Nanggroe.

In other words, the Chairman of the DPRA also sought a secured position to maintain the power as a member of the Aceh Party and as the Chairman of the DPRA. There have been efforts made by legislators from the national parties that got seats in the DPRA so that Wali Nanggroe is involved in resolving conflicts and executive-legislative political communication, this effort has been conveyed through the mass media. However, the internal rules in the DPRA regulate that each idea should be communicated to and will be followed up by the Chairman of the DPRA.

\subsubsection{The Tendency to Maintain and Strengthen the Reigns}

All of the elite including Wali Nanggroe, have tendencies to maintain the reigns, it is difficult to do a conflict resolution due to their neutrality. The Governor has observed the situation and the grand design of the Aceh Party's dependency cycle with Wali Nanggroe and vice versa. The neutrality of Wali Nanggroe is still doubtful as a mediator of executive-legislative conflicts and other social conflicts in Aceh.

The description above shows that Wali Nanggroe procedurally elected by a special team known as the Assembly Council. If Wali Nanggroe is elected by an internal assembly session in the institution, then the current Wali Nanggroe could not be re-elected. Therefore, legislators ignore the electoral process under legal norms, maintaining the status quo by carrying out their elections through Members of the Aceh Provincial House of Representatives (DPRA). The political consolidation between Wali Nanggroe and members of the Aceh Party legislature is to strengthen the position as part of the reign orientation of the party elite. This conflict and chaotic communication will continue to emerge if the form of politics that is built up in Aceh is still like patronage politics. The political interests of the authorities are more dominant than building accommodative political communication.

Wali Nanggroe and the Aceh Party have strong relations since these two institutions were from the same house. They were born from the same history, bounded many links, and defended each other. GAM is fighting for its party. Likewise, the Aceh Party strongly supported Wali Nanggroe, whereas Wali Nanggroe strengthened the existence of the Aceh Party and GAM in the Aceh political order. Departing from the struggle, the role of mutual defense and mutual defense of authority must be part of the movement's history. Therefore, this is led to the Wali Nanggroe Institution as a non-neutral and leads to personal gain. The people can be ignored if these institutions do not professionally put their respective positions. Mutual support for GAM, the Aceh Party, and Wali Nanggroe in the view of the people as impartial.

\subsubsection{Internal Problems during Wali Nanggroe Election Process}

In addition to the neutrality of Wali Nanggroe as the mediator of conflict resolution and the chaotic political communication between the legislature and the executive, this institution faces its internal problems, namely in the election process. Where Wali Nanggroe should be elected in a special council chosen to elect the Wali, the legislative role cannot be made an executor in the election of Wali Nanggroe. In other words, Aceh legislators were not given the authority to elect Wali Nanggroe, but in practice, Wali Nanggroe was still elected by legislators.

Even though the Minister of Home Affairs of the Republic of Indonesia is not to interfere in this matter, the Minister of Home Affairs expects the election of Wali Nanggroe always happens. Katibul Wali is an apparatus that works within the Wali agency and cannot do much in electoral matters. Although there are already rules governing Wali Nanggroe, Katibul Wali is still 
worried that the election will not accord to the procedure. The disbursement of funds for the Wali Nanggroe election was also concerned. If the election is not following the existing rules, the Minister of Home Affairs will not tolerate the results. Moreover, the lack of human resources (HR) in Katibul Wali Council, both in the knowledge of the Wali Nanggroe's Qanun and the Wali Nanggroe Institution.

After 2017, the year of a political event, many legislative members from national parties in the province and legislative members from local parties that will advance in the 2019 Legislative Elections. The event is largely determined by the role of the Wali Nanggroe In particular the legislative members of the Aceh Party their fate is very much determined by the point of Wali Nanggroe. Wali Nanggroe decides who will be the candidates from the Aceh Party and from the Aceh legislature that can be back to the political arena in 2019.

It can be said that those who are in the Wali Nanggroe Institution and those around Wali are very weak. The weaknesses of those around the Wali Nanggore Institution make it very difficult to develop political communication among institutions including the executivelegislature. It is since they do not understand their role mandated by the Qanun. Like Katibul Wali that can advise Wali Nanggroe to be involved in conflicts that occur between the executive and legislative branches of Aceh. The strong political influence of Wali Nanggroe in Aceh was made this moment as an instrument of perpetuating power by legislators from the Aceh Party. The event of obtaining the political blessing of the Wali greatly determines the fate of GAM who is active in practical politics. If there are members of the Aceh Party or from GAM who are no longer in line with the mandate of Wali Nanggroe and its commanders, then that person will be considered a betrayer of the struggle and treated the same as what they have treated Irwandi Yusuf and his members. This growing reality and tradition created the political attitude and policy of the governor's political communication by not involving and allowing Wali Nanggroe to be involved in the chaotic political communication between the executive and the legislature. Irwandi Yusuf had read the scenario in Aceh's political order if Wali Nanggroe is involved. The result is that the executive must be disadvantaged due to the mediator is unfair and not neutral, such as Wali Nanggroe's role as the third actor for conflict resolution.

\section{Conclusion}

Wali Nanggroe does not implement any strategy in conflict resolution between institutions and between communities. Wali Nanggroe is very passive in responding to social phenomena that occurred in Aceh. So that its role as a mediator of conflict cannot be carried out optimally and does not in line with the theory of conflict resolution as a mediator in resolving the conflict. Communication strategies in resolving political and social conflicts and institutions in Aceh should involve third parties or additional actors as mediators.

Wali Nanggroe is considered a non-neutral institution to mediate conflicts. Mediation should be a neutral party and can be a role model for the public in Aceh. The existence of Wali Nanggroe, which is considered as a role model for mediators between institutions, faces resistance from the public and the executive. The non-neutral of Wali Nanggroe due to the emotional attachment between Wali Nanggroe and Aceh Provincial House of Representatives (DPRA) members from the Aceh Party (PA) and the tendency to maintain and strengthen reigns for long periods. If Wali Nanggroe is elected by the voters, there is a concern that they will not be re-elected; this reason makes Wali Nanggroe takes advantage of the members of DPRA from the Aceh Party to be elected. Wali Nanggroe is part of the Aceh Party advisor and the party was as a protector to perpetuate the reign of the Wali to be re-elected by the Member of DPRA as Wali Nanggroe.

Copyright (C) 2020. Owned by Author(s), published by Society. This is an open-access article under the CC-BY-NC-SA license. https://doi.org/10.33019/society.v8i2.192 
Wali Nanggroe Institution must resolve conflicts between institutions and social conflicts in Aceh in line with the existing conflict resolution strategies. The Wali Nanggroe Institution also must be neutral and open, alert to occurred conflicts, and neutral when attended and requested as mediators to resolve social conflicts and political communication. Besides, a mediator is the one approved by all parties. So that conflicts among institutions have a common ground and mutual benefit. This institution should learn from the experience of Aceh conflict between the Indonesian Government and GAM that mediated by the European Union, Martti Ahtisaari, the President of the Crisis Management Initiative (CMI) that impacted on Aceh peace from the conflicts of GAM against the Government of the Republic of Indonesia.

\section{Acknowledgment}

The author would like to thank Wali Nanggroe Institution (Tuha Peut, the Chairperson of Wali Nanggroe), the Chairman of Aceh House of Representatives (DPRA) Commission I from the Aceh Party (PA) Faction, the Vice-Chairman of DPRA Commission IV and Chairperson of National Mandate Party (PAN) Faction, Administrative Section Head of Aceh Legislation Regulations, Assistant for the Government at the Aceh Regional Secretariat, Senior Legal Expert of Syiah Kuala University, Chairman of the DPRA from the Aceh Party (PA) Faction, Member of Parliament at DPRA from the United Development Party (PPP) Faction, Member of Parliament at North Aceh Regency House of Representatives (DPRK Aceh Utara) from Democratic Party Faction, and Academicians of Malikussaleh University. Also, the author would like to thank all people had contributed to this research.

\section{Declaration of Conflicting Interests}

The author declared no potential conflicts of interest concerning the research, authorship, and/or publication of this article.

\section{References}

Abdullah, M. A. (2016). Kedudukan Wali Nanggroe Setelah Lahirnya Undang-Undang Pemerintahan Aceh. Kanun: Jurnal Ilmu Hukum, 18(2), 279-287. Retrieved from http://www.jurnal.unsyiah.ac.id/kanun/article/view/5925

Amantjik, F. R. R., Dermawan, W., \& Akim, A. (2019). Conflict Resolution in South Sudan. Jurnal ICMES : The Journal of Middle East Studies, 3(1), 53-74. https://doi.org/10.35748/jurnalicmes.v3i1.44

Anwar, S. (2015). Membangun kembali perdamaian: Rekonsiliasi konflik komunal berbasis trust. KRITIS: Jurnal Ilmu Sosial dan Ilmu Politik Universitas Hasanuddin, 1(1), 133-142.

Retrieved from http://journal.unhas.ac.id/index.php/kritis/article/view/8

Cangara, H. (2014). Perencanaan Strategi Komunikasi. Jakarta: RajaGrafindo Persada.

Effendy, O. B. (2007). Ilmu, Teori dan Filsafat Komunikasi. Bandung: Citra Aditya Bakti.

Febrianti, S., Arum, A., Dermawan, W., \& Akim, A. (2019). Internal Conflict Resolution between Government of Indonesia and Separatist Movement in Papua using Horse-Trading Mechanism. Society, 7(2), 83-100. https://doi.org/10.33019/society.v7i2.86

Heridiansyah, J. (2014). Manajemen konflik dalam sebuah organisasi. Jurnal STIE Semarang (Edisi Elektronik), 6(1), 28-41. Retrieved from http://jurnal3.stiesemarang.ac.id/index.php/jurnal/article/view/106 Husin, T. (2013). Kapital Selekta Hukum Adat Aceh dan Qanun Wali Nanggroe. Banda Aceh: Bandar Publishing. 
Khomsahrial, R. (2014). Komunikasi Organisasi Lengkap. Jakarta: Gramedia Pustaka Utama.

Liliweri, A. (2018). Prasangka, Konflik \& Komunikasi Antar Budaya. Jakarta: Kencana Prenada Media Group.

Moleong, L. J. (2010). Metodologi Penelitian Kualitatif. Bandung: Remaja Rosdakarya.

Muspawi, M. (2014). Manajemen Konflik (Upaya Penyelesaian Konflik dalam Organisasi). Jurnal Penelitian Universitas Jambi: Seri Humaniora, 16(2), 41-46. Retrieved from https:/ / www.neliti.com/publications/43447/manajemen-konflik-upaya-penyelesaiankonflik-dalam-organisasi

Nurlian, N. (2018). Konflik Tanah Hibah Masyarakat Nelayan dengan Pemerintah Kabupaten Aceh Barat. Community: Pengawas Dinamika Sosial, 4(2), 177-187. https://doi.org/10.35308/jcpds.v4i2.990

Pemerintah Aceh. (2012). Qanun Aceh Nomor 8 Tahun 2012 Tentang Lembaga Wali Nanggroe. Lembaran Aceh Tahun 2012 Nomor 8. Banda Aceh: Sekretariat Daerah Aceh. Retrieved from http://simeuluekab.go.id/uploads/Qanun_Aceh_Nomor_8_Tahun_2012__Lembaga_Wali_Nanggroe.pdf

Rasyidah, R. (2014). Potensi Konflik dan Masa Depan Islam di Indonesia (Kajian Terhadap Tantangan Dakwah). Jurnal Al-Bayan: Media Kajian dan Pengembangan Ilmu Dakwah, 20(2), 49-62. Retrieved from https://jurnal.ar-raniry.ac.id/index.php/bayan/article/view/123

Rifa'i, A. (2010). Konflik dan Resolusinya Dalam Perspektif Islam. Millah: Jurnal Studi Agama, 10, 171-186. https:/ / doi.org/10.20885/millah.ed.khus.art10

Sahlan, M., Fajarni, S., Ikramatoun, S., Kamil, A., \& Ilham, I. (2019). The Roles of Ulama in the process of Post-Conflict Reconciliation in Aceh. Society, 7(2), 251-267. https://doi.org/10.33019/society.v7i2.106

Sugiyono, S. (2009). Metode Penelitian Pendidikan Pendekatan Kuantitatif, Kualitatif dan R\&D. Bandung: Alfabeta.

Tualeka, M. W. N. (2017). Teori Konflik Sosiologi Klasik Dan Modern. Al-Hikmah, 3(1), 32-48. Retrieved from http://103.114.35.30/index.php/Ah/article/view/409

\section{About the Author}

Zulham Ibrahim, obtained his Bachelor degree in Political Science from Aligarh Muslim University, India, in 1998 and Magister degree in Political Science from Bangalore University, India, in 2002. The author is an Assistant Professor at the Department of Political Science, Faculty of Social and Political Sciences, Malikussaleh University, Indonesia.

E-Mail: zulhambere@gmail.com 